\title{
Serving the Millennial Generation
}

\author{
Edited by Michael D. Coomes, Robert DeBard
}

Published by Jossey-Bass 2004, 104 pages

Reviewed by

Denise L. Rode (drode@ @iu.edu), Director of First-Year Experience \& Orientation, Northern Illinois University

One of the strengths of the Jossey-Bass "New Directions for Student Services" series is that it pulls together the most current thinking on a topic in higher education in a concise and coherent way. In this regard, Serving the Millennial Generation, a monograph edited by Michael D. Coomes and Robert DeBard (both professors of higher education at Bowling Green State University), does not disappoint.

As stated by the editors in their preface, "The purpose of this New Directions sourcebook is to explore the cycle of generations as a source of insight for making the lives of our students intelligible to students affairs personnel who. . .serve members of this emerging generation" (p. 1). Certainly, orientation staff members need to understand the unique characteristics, values, and needs of this traditional-aged student population, because they (orientation staff) are some of the first interpreters of the college experience for new students. Administrative decisions and programmatic designs hinge on having an up-to-date understanding of the students we serve.

Although many orientation professionals are generally familiar with the terms "Millennials" and "helicopter parents" through the popular media, it is valuable to take a more scholarly, research-based look at the forces shaping the present student cohort. In Chapter 1, Coomes and DeBard establish a conceptual framework and present a model of generational succession that examines how members of one generation interact with and are influenced by other generations. This chapter provides an essential foundation which draws upon the work of Strauss and Howe (1991), Levine and Cureton (1998), and other respected generational researchers. It establishes that the Millennial generation (the 80 million+ Americans born after 1981) will be the largest cohort in the nation's history. The chapter concludes with an important caveat: "a generational perspective should be employed with caution. Like many megatheories, it can lead to stereotyping and overgeneralization" (p. 13).

Chapter 2, written by Coomes, explores how history and popular culture can be useful lenses for understanding generations. Drawing on the work of Schlesinger (1986), Levine (1981), and Ortega y Gasset (1944; 1992), the author establishes that history 
oscillates between periods of innovation and conservatism, a concern for the rights of the individual and responsibilities to the community, and an emphasis on public purpose and private interest (p. 19). Understanding the cyclical nature of generations is vital to how generations interact and respond to each other.

Coomes identifies the O.J. Simpson trial, the Columbine High School shootings, and the terrorist attacks of September 11, 2001, as some of the defining moments for the Millennials. He also emphasizes that the effect of popular culture in the forms of media, technology, games, music, fashion, and sports should not be overlooked. This is a generation marked by technological literacy; the ascendancy of strong, independent, capable women; the prevalence of rap/hip hop music; and the ability to be constantly connected with others via cell phone, e-mail, IM, and discussion boards.

DeBard focuses in Chapter 3 on seven characteristics of Millennial college students as identified by Howe and Strauss (2003): 1) their "specialness" (reinforced by their Boomer generation parents); 2) their shelteredness from harm's way (through encouragement from authorities to "follow the rules" which are structured and clearly communicated); 3) their confidence (fostered by a trust in authority that has worked well for them in the past); 4) their adherence to convention (accepting the social rules of Boomer authority figures who have rewarded such behavior); 5) their team orientation (as seen in their willingness to cooperate and their desire to congregate); 6) their drive for achievement; and 7) the pressure they feel to perform and excel (having been pushed by their Boomer parents to be the best they can be).

Chapter 3 delves deeper into generational theory by comparing and contrasting the generational values of Boomer parents, faculty, and staff with those of the Millennial students they parent, teach, and serve. An illuminating chart in this chapter sets out the dominant values of Baby Boomers, Gen Xers, and Millennials, helping the reader see the particular strengths and challenges of serving the current cohort of traditional-aged students.

DeBard depicts Millennials as academically optimistic, service-oriented, politically engaged, and less experienced than earlier generations with alcohol, cigarettes, drugs, and premarital sex. These students tend to follow rules, as long as they are diligently enforced and well explained. As a group, they tend to be hardworking, cheerful, earnest, and deferential. Challenging characteristics of this generation include a tendency to study less (although high school grades do not reflect this due to grade inflation), higher expectations for college performance than may be warranted, and working many hours off campus.

C. Carney Strange contributed one of the most valuable chapters of this sourcebook"Constructions of Student Development Across the Generations." Here, Strange investigates the dynamics of generational cohort differences and their potential influence on commonly accepted student development theories. Provocative questions are raised about the applicability of theories and models which were developed on the Baby Boomers of the 1960s and 1970s. The reader is asked to consider how psychosocial, cognitive developmental, and personal preference/personality type/learning style approaches may need to be revised in order to guide our practice with the Millennial 
generation.

Chapter 5 takes up the topic of effectively teaching Millennial students and fostering their learning in the classroom. Author Maureen E. Wilson counsels quality studentfaculty contact, class activities that involve study groups and other team assignments, active learning strategies, student-centered pedagogy, frequent feedback from instructors, and time on task. She contends that Millennials may need help in developing reflective, critical thinking skills. Coming from structured precollege lives where high achievement came easily, Millennial students may have unrealistic expectations about what is required to be successful in college. Wilson also addresses the prevalence of parent involvement; the expectations Millennials have for cutting-edge technology on campus; the need to address academic dishonesty (especially plagiarism) and to clearly communicate expectations for academic standards; and the growing number of students with disabilities on college campuses.

In Chapter 6, Ellen M. Broido tackles the topic of shifting campus demographicsespecially the diversity of the Millennial Generation. Student affairs staff need to be aware of the rising number of immigrant, minority, and biracial students; an increase in the number of students who identify as lesbian, gay, bisexual, or transgender; and higher percentages of students who come from single-parent families, blended and stepfamilies, and families with same-sex parents. Broido outlines Millennial perspectives on race and racism, gender and sexism, sexual orientation and heterosexism, political attitudes, and social justice issues. Implications for student affairs practice are discussed.

The final chapter, contributed by John Wesley Lowery, offers insights into the design and delivery of student affairs programs and services. He suggests that student affairs professionals educate students and parents about resolving complaints and concerns by using appropriate institutional channels. Lowery also expresses concern that Millennials' comfort with and frequent use of technology may be an obstacle to the development of relationships and independence in college. He postulates that Millennials will require convenient, online, instantaneous service because they have grown up in a world of instant gratification. Because of this generation's emphasis on achievement, teamwork, and convention, he foresees a heightened interest in campus organizations, stress reduction strategies, and campus wide events.

While this sourcebook mentions orientation programs only peripherally, it proves to be an indispensable resource for orientation professionals. First, it provides essential background we need to know in order to adequately serve today's students. Second, excerpts can be used in training student orientation leaders as well as in educating campus colleagues about the Millennial generation and the differences between traditional-aged students and the Gen X, Baby Boomer, and "Silent Generation" faculty and staff who work with them. Third, it offers clues for how administrators can design or adapt programs and services to effectively meet the needs of Millennials and their families. And fourth, it forces us to take a critical look at existing student development theories to determine how well they describe our student populations.

Orientation directors often have multiple responsibilities and limited time for professional reading. That perhaps is one of the best reasons for accessing a hard copy or 
online version of this journal. Each chapter reads quickly and is easily grasped by new and seasoned professionals alike. Each chapter can stand alone as a useful essay for training and discussion. If there is a weakness in this publication, it is that there is a certain amount of redundancy between/among chapters in descriptions of the Millennial generation. 